\title{
KEPASTIAN HUKUM DAN KONSEP KEDEPAN TERKAIT PENGANGKATAN PEGAWAI NEGERI SIPIL (PNS) BAGI SEKRETARIS DESA (SEKDES) DI INDONESIA
}

\author{
Oleh : \\ Muhammad Hoiru Nail \\ Email: hoirunail88@gmail.com \\ Fakultas Hukum Universitas Islam Jember \\ Suphia \\ Email:Suphia@uij.ac.id \\ Fakultas Hukum Universitas Islam Jember
}

\begin{abstract}
Abstrak
Pegawai Negeri Sipil (PNS) merupakan sebuah jabatan yang mana masyarakat membantu negara dalam menjalankan tugas dan kewenangan pada pelaksaaan fungsi pemerintahan. Pasal 202 Ayat (3) Undang-Undang Republik Indonesia Republik Indonesia Nomor 32 Tahun 2004 tentang Pemerintahan Daerah mengamanatkan pengisian jabatan Sekretaris Desa diisi dengan jabatan PNS, tentu ini menjadi kabar gembira bagi Sekretaris Desa yang ada karena berpeluang menjadi PNS. Seiring berjalannya waktu dasar hukum penyelenggaraan Pemerintahan Daerah yang lama telah dicabut dan memberlakukan Undang-Undang Republik Indonesia Nomor 23 Tahun 2014 tentang Pemerintahan Daerah. pemberlakuan UndangUndang Pemerintahan Daerah yang baru ini tentu memiliki dampak terhadap beberapa aspek pengaturan dalam hukum pemerintahan daerah, tidak terkecuali jabatan sekdes yang dapat diangkat menjadi PNS.
\end{abstract}

Kata Kunci: Pegawai Negeri Sipil, Sekretaris Desa

\begin{abstract}
Abstrak
Civil servants are a position when the community assists the state in carrying out its duties and authorities in the implementation of goverment fungtions. Article 202 paragraph 3 of the republik of Indonesia law number 32 of 2004 concering regional goverment mandates filling the position of village secretary to be filled by civil servant, of course this is good news for the exiting village secretaries because they have the opportunity to became civil servant. Over time the old legal basis for the adminstration of regional goverment has been revoked and the Republik of Indonesia law No.23/2014 on regional governance has been enacted. The enactment of this new regional goverment law certainly has an impact on several regulatory aspects in regional goverment law, including the position of village secretary who can be appointed as a civil servant.
\end{abstract}

Keyword: Civil Servant, village secretary 


\section{PENDAHULUAN}

\subsection{Latar Belakang}

Negara Kesatuan Republik Indonesia (NKRI) merupakan sebuah negara yang terdiri dari susunan-susunan kewilayahan. ${ }^{1}$ Secara konstitusional hal tersebut dinyatakan tegas bahwa wilayah-wilayah tersebut terdiri dari wilayah provinsi, kemudian wilayah provinsi dibagi atas kabupaten dan kota. Undang-Undang Dasar Negara Republik Indonesia Tahun 1945 (selanjutnya dalam tulisan ini akan ditulis UUD NRI Tahun 1945) hanya menyebutkan secara tegas sampai pada wilayah kabupaten kota saja, namun nyatanya ada pemerintahan yang berada pada wilayah kabupaten kota tersebut yakni Pemerintahan Desa. ${ }^{2}$

\footnotetext{
1 Lihat Pasal 18 Ayat (1) UUD NRI Tahun 1945. "Negara Kesatuan Republik Indonesia dibagi atas daerah-daerah provinsi dan daerah provinsi itu dibagi atas kabupaten dan kota, yang tiap-tiap provinsi, kabupaten, dan kota itu mempunyai pemerintahan daerah, yang diatur dengan undang-undang" Pasal 18 Ayat (2) ini merupakan hasil perubahan UUD kedua yang dilakukan oleh Majelis Permusyawaratan Rakyat Indonesia dan disyahkan pada tanggal 18 Agustus 2000.

2 Keadaan tersebut ditandai dengan fakta hukum dalam Peraturan Perundang-undangan yakni adanya UU tersendiri yang mengatur tentang Penyelenggaraan Pemerintahan Desa dalam sistem NKRI. Selanjutnya lihat Pasal 1 Angka (3) Undang-Undang Republik Indonesia Nomor 6 Tahun 2014 tentang Desa. "Pemerintah Desa adalah Kepala Desa atau yang disebut dengan nama lain dibantu perangkat desa sebagai unsur Penyelenggara Pemerintahan Desa”. Pasal 2 Ayat (2) Undang-Undang Republik Indonesia Nomor 23 Tahun 2014 tentang Pemerintahan Daerah. "Daerah Kabupaten/Kota dibagi atas kecamatan dan kecamatan dibagi atas kelurahan dan/desa".
}

Keberadaan Desa merupakan entitas penyelenggara urusan pemerintahan terkecil dalam sistem penyelenggaraan pemerintahan NKRI. Bagi Indonesia, penyelenggaraan pemerintahan Desa yang berkualitas berpotensi mendorong kesejahteraan masyarakat Desa, sekaligus meningkatkan kualitas hidup di Desa. Sebagai strata pemerintahan terkecil, Desa memainkan peran sentral dalam agenda pembangunan nasional di mana sebagian masyarakat Indonesia hidup di pedesaan. ${ }^{3}$

Pemerintahan Desa sendiri merupakan ujung tombak pembangunan yang secara langsung berhubungan dengan masyarakat, oleh karenanya dari sudut pandang ilmu pemerintahan dirasa perlu struktur dari pemerintahan desa yang lengkap, representatif serta negara/pemerintah ikut hadir secara langsung melalui aparatur negaranya dalam struktur/aparatur pemerintahan desa. Dari sudut pandang ilmu hukum struktur/ aparatur perangkat pemerintahan desa tersebut menjadi bagian tidak terpisahkan dari ilmu peraturan perundang-undangan/ aspek hukum guna mencapai kepastian hukum, keadilan hukum serta kemanfaatan.

\footnotetext{
3 Irwan Tahir, Sejarah Perkembangan Desa di Indonesia, Desa di Masa Lalu, Masa Kini dan bagaimana Masa Depannya, Jurnal MIPI, Edisi 38 tahun 2013, Jakarta, hlm. 17 Lihat juga Sutrino Purwohadi Mulyono, Sinergitas Penyelenggaraan Pemerintahan Desa Pasca pemberlakuan UU No. 6 Tahun 2014 tentang Desa, Jurnal MMH, Jilid 43 No. 3 Juli 2014, hlm. 430.
} 
Mengutip pendapat Dadang Sufianto, bahwa secara pendekatan historis ilmu pemerintahan (dalam konteks tulisan ini yakni mencakup pemerintahan desa) tidak dapat dipisahkan oleh hukum/peraturan perundang-undangan.

Dilihat dari pendekatan historis, ilmu pemerintahan tidak dapat dipisahkan dari aspek peraturan/ hukum yang mengatur tata laksana pemerintahan. sejarah pemerintahan dijalankan sesuai dengan peraturan/ hukum yang telah ditetapkan, baik tertulis maupun tidak tertulis. $^{4}$

Dalam penelitian ini secara tegas secara prinsip sangat setuju/sependapat dengan apa yang disampaikan oleh Dadang Sufianto tersebut, dalam kontek ini berarti penyelenggaraan pemerintahan desa tentu tidak lepas dari aturan/peraturan sebagai tata laksana pemerintahan desa. Dengan aturan tersebut maka diharapkan penyelenggaraan pemerintahan desa dapat berjalan dengan efektif, efisien, akuntabilitas, transparansi serta pelayanan yang maksimal terhadap masyarakat.

Berdasarkan hal tersebut, maka pemerintahan desa merupakan ujung tombak pembangunan dan bersinggungan langsung dengan kebutuhan dan pelayanan kepada masyarakat. Dengan begitu tentunya dibutuhkan sebuah pemerintahan desa yang

\footnotetext{
4 Dadang Sufianto, Pengantar Ilmu Pemerintahan, Pustaka Setia, Bandung, 2015, hlm 31
}

dapat memberikan pelayanan yang prima bagi masyarakatnya, salah satu bentuk intervensi dari negara (pemerintah) guna pemberian pelayanan yang prima tersebut ditetapkan ketentuan Pasal 202 Ayat (3) Undang-Undang Republik Indonesia Nomor 32 Tahun 2004 tentang Pemerintahan Daerah ${ }^{5}$ (selanjutnya dalam tulisan ini akan ditulis UU Pemda lama/terdahulu).

Pemerintahan desa dilihat dari sudut pandang ilmu pemerintahan termasuk dalam ruang lingkup ilmu pemerintahan, khususunya pada bidang ketatalaksanaan (administrasi pemerintahan desa). ${ }^{6}$ Dengan begitu kajian atas penyelenggaraan pemerintahan desa dalam kajian tulisan ini akan bersinggungan baik langsung atau tidak langsung dengan ilmu pemerintahan yang selalu mengedepankan clean and good governance/pemerintahan yang baik dan bersih.

Rezim UU Pemda terdahulu mengamanatkan agar pengisian jabatan Sekretaris Desa diisi dari PNS, tentu ini merupakan kabar gembira bagi pemerintahan desa khususnya bagi mereka yang saat itu menjabat sebagai Sekretaris Desa karena

5 Pasal 202 Ayat (1) Undang-Undang Republik Indonesia Nomor 32 Tahun 2004 tentang Pemerintahan Daerah "Pemerintah desa terdiri atas kepala desa dan perangkat desa". Ayat (2) "Perangkat desa terdiri dari Sekretaris Desa dan perangkat desa lainnya". Ayat (3) "Sekretaris Desa sebagaimana dimaksud pada ayat (2) disisi dari pegawai negeri sipil yang memenuhi persyaratan.

6 Taliziduhu Ndraha, Metodologi Ilmu Pemerintahan, Rineka Cipta, Jakarta, 1997, hlm. 31 
dengan ketentuan tersebut dirinya sangat memungkinkan diangkat menjadi PNS. Terlepas dari ini hal tersebut, kajian ilmiah ini menganggap hal tersebut sangatlah beralasan menurut hukum sebab dengan diisinya jabatan Sekretaris Desa dengan jabatan PNS ini menandakan pemerintah serius hendak ikut andil dalam menjalankan pemerintahan yang clean and good governance.

Pemerintah kemudian dengan amanat ketentuan Pasal 202 Ayat (3) UU Pemda terdahulu tersebut dengan sigap mengeluarkan aturan lebih lanjut untuk mengatur tata cara pengangkatan Sekretaris Desa menjadi PNS yakni dengan mengeluarkan Peraturan Pemerintah (PP) Nomor 45 Tahun 2007 tentang Persyaratan dan Tata Cara Pengangakatan Sekretaris Desa Menjadi Pegawai Negeri Sipil. Selanjutnya melalui Kementerian Dalam Negeri saat itu telah dikeluarkan Peraturan Menteri Dalam Negeri (Permendagri) Nomor 50 Tahun 2007 tentang ketentuan Pelaksanaan Peraturan Pemerintah Nomor 45 Tahun 2007 tentang Persyaratan dan Tata Cara Pengangakatan Sekretaris Desa Menjadi Pegawai Negeri Sipil.

Menurut Sadu Wasistiono, pengisian jabatan Sekretaris Desa oleh PNS dilatar belakangi oleh Ketentuan Ketetapan Majelis Permusyawaratan Rakyat Republik Indonesia Nomor IV/MPR/2000 tentang Rekomendasi Kebijakan Dalam
Penyelenggaraan Otonomi Daerah khususnya rekomendasi Nomor 7 yang substansi isinya adalah kemungkinan pemberian otonomi bertingkat terhadap Propinsi, Kabupaten/Kota, serta Desa/Nagari/ Marga, dan sebagainya. ${ }^{7}$

Menarik untuk dikaji dan diteliti, sebab keberlakuan UU Pemda terdahulu tersebut sudah dinyatakan tidak berlaku dengan diberlakukannya UU pemerintahan Daerah yang baru yakni Undang-Undang Republik Indonesia Nomor 23 Tahun 2014 tentang Pemerintahan Daerah. ${ }^{8}$ setelah dilihat kembali dan ditelaah tidak ada satu ketentuanpun didalam UU tersebut yang mengatur mengenai pemerintahan desa. Dengan begitu pemerintahan desa sendiri memang sengaja dihilangkan oleh pembentuk UU (Presiden dan DPR) karena terkait pemerintahan desa sendiri pemerintah (Presiden) bersama-sama dengan DPR telah menetatpkan Undang-Undang Republik Indonesia Nomor 6 Tahun 2014

\footnotetext{
7 Sadu Wasistiono dan M. Irwan Tahir, Prospek Pengembangan Desa, Fokus Media, Bandung, 2007, hlm. 33 lihat juga Didik Chusnul Yakin dkk, Pengaruh Implementasi Kebijakan, Karakteristik Individu, Karakteristik Organisasi Terhadap Motivasi Kerja dan Kinerja Sekretaris Desa di Kabupaten Mojokerto. Jurnal Adminsitrasi Publik, Juni 2013, Vol. 11, No.1, hlm.129.

8 Dalam Perkembangannya UU Pemerintahan Daerah tersebut telah mengalami perubahan, ketentuan terakhir yang digunakan dan diberlakukan terkait hukum pemerintahan daerah yakni Undang-Undang Republik Indonesia Nomor 9 Tahun 2015 tentang Perubahan Kedua Atas Undang-Undang Nomor 23 Tahun 2014 tentang
} Pemerintahan Daerah. 
tentang Desa (selanjutnya dalam tulisan ini akan ditulis UU Desa).

Penuluran lebih lanjutpun dilakukan pada UU Desa, namun tidak didapati dasar hukum mengenai jabatan Sekretaris Desa diisi dengan PNS. Dengan begitu rezim atau pengaturan pengisian jabatan Sekretaris Desa yang semula diisi dengan jabatan PNS saat ini sudah tidak berlaku lagi atau dengan kata lain hukum pemerintahan daerah termasuk pula UU desa tidak ada pengaturan mengenai jabatan Sekretaris Desa diisi oleh jabatan PNS.

Berdasarkan uraian tersebut diatas, menarik untuk dikaji dan diteliti lebih lanjut tentunya dari sudut pandang ilmu hukum terkait kepastian hukum pengangkatan PNS bagi Sekretaris Desa. Beberapa faktor yang menjadi bahan kajian termasuk diantaranya bagaimana keberlakukan PP 45 Tahun 2007, Permendagri Nomor 50 Tahun 2007 dari sudut ilmu perundang-undangan. Kajian dan penelitian ini juga akan menyinggung seberapa penting jabatan PNS perlu diadakan/dihadirkan pada pemerintahan desa.

\subsection{Rumusan Masalah}

Berdasarkan uraian/paparan dalam latar belakang tersebut maka dapat ditaruk sebuah rumusan masalah yang akan dikaji dan diteliti lebih lanjut yakni. Pertama, bagaimana kepastian hukum Sekretaris Desa saat (yang menjabat saat ini) dengan keberlakuan UU Nomor 9 Tahun 2015. Kedua, Bagaimana pengaturan kedepan terkait jabatan Sekretaris Desa di masa yang akan datang.

\section{METODOLOGI PENELITIAN}

Metodologi yang digunakan dalam penelitian karya tulis ilmiah ini ialah metodologi penelitian hukum normatif, yakni sebuah penelitian ilmiah pada bidang ilmu hukum yang mengkaji hukum positif dan berbagai macam asas-asas/ prinsipprinsip hukum yang berkembang pada ilmu hukum. penelitian ini melakukan pengkajian terhadap berbagai macam regulasi yang ada/peraturan perundang-undangan baik vertikal maupun horizontal yang memiliki keterkaitan dengan tema penelitian dalam karya tulis ini.

\section{PEMBAHASAN}

Pertama, atas kajian rumusan pertama ini maka pada mulanya akan diawali mengenai tidak terlepasnya tujuan umum dari hukum itu sendiri yakni tujuan keadilan, kemanfaatan dan kepastian hukum. kepastian hukum memang menempati urutan ketiga atau terakhir dalam tujuan hukum, namun pada dasarnya atau pada akhirnya dengan kepastian hukumlah sebuah keadilan dan kemanfaatan hukum dapat dirasakan/ terlaksana. 
Pada mulanya sejak diundangkan UU Pemda lama/terdahulu, tidak serta merta ketentuan Pasal 202 Ayat (3) yang mengamanatkan pengisian jabatan Sekretaris Desa diisi oleh PNS langsung terlaksana, setidaknya terdapat jeda waktu kurang lebih 3 tahun peraturan pelaksana atas ketentuan pasal tersebut terbit. ${ }^{9} \quad$ Tepatnya sejak diterbitkannya Peraturan Pemerintah (PP) 45 Tahun 2007 tentang Persyaratan dan Tata Cara Pengangakatan Sekretaris Desa Menjadi Pegawai Negeri Sipil dan (Permendagri) Nomor 50 Tahun 2007 tentang ketentuan Pelaksanaan Peraturan Pemerintah Nomor 45 Tahun 2007 tentang Persyaratan dan Tata Cara Pengangkatan Sekretaris Desa Menjadi Pegawai Negeri Sipil.

Sejak tahun 2007 itulah pemerintah melalui Kemendagri dan kementerian terkait $^{10}$ melakukan inventarisasi dan pengangkatan Sekretaris Desa menjadi PNS. Namun dalam kenyataannya tidak sedikit pula dari daftar inventarisasi tersebut terdapat Sekretaris Desa yang tidak memenuhi kualifikasi untuk diangkat menjadi PNS, sehingga untuk mengatasi

\footnotetext{
${ }^{9}$ Syarat dan tata cara pengangkatan Sekretaris Desa menjadi PNS tidak masuk dalam kajian tulisan ini. Selengkanya terkait syarat dan tata cara pengangkatan Sekretaris Desa dapat diangkat menjadi PNS dapat dilihat pada ketentuan tersebut diatas.

${ }^{10}$ Kementerian terkait tersebut antara lain Kementerian Pendayaan Aparatur Negara dan Reformasi Birokrasi kemenpan RB, serta pemerintah daerah kabupaten/kota.
}

keadaan tersebut pemerintah melalui kemendagri mengeluarkan kembali aturan/ produk hukum berupa Permendagri Nomor 21 Tahun 2008 tentang Perubahan Atas Peraturan Menteri Dalam Negeri Nomor 50 Tahun 2007 tentang Ketentuan Pelaksanaan Peraturan Pemerintah Nomor 45 Tahun 2007 tentang Persyaratan dan Tata Cara Pengangkatan Sekretaris Desa Menjadi Pegawai Negeri Sipil.

Sekretaris Desa yang menurut ketentuan dan syarat pengangkatan tidak dapat diangkat sebagai PNS diberhentikan oleh bupati/walikota setelah masa jabatannya habis/selesai serta diberikan kompensasi atas pengabdian yang telak dilaksanakan selama bertugas. ${ }^{11}$ Dengan demikian bahwa fenomena pengangkatan Sekretaris Desa pada saat itu terdapat 2 (dua) kemungkinan yakni yang memenuhi syarat dan ketentuan diangkat menjadi PNS dan bagi yang tidak memenuhi syarat dan

11 Pasal 7 Ayat (1) Permendagri Nomor 21 Tahun 2008 tentang Perubahan Atas Peraturan Menteri Dalam Negeri Nomor 50 Tahun 2007 tentang Ketentuan Pelaksanaan Peraturan Pemerintah Nomor 45 Tahun 2007 tentang Persyaratan dan Tata Cara Pengangkatan Sekretaris Desa Menjadi Pegawai Negeri Sipil. "Sekretaris Desa yang tidak memenuhi persyaratan untuk diangkat menjadi PNS, diberhentikan oleh bupati/walikota setelah habis masa jabatannya". Ayat (2) "Sekretaris Desa yang diberhentikan dari jabatannya sebagaimana dimaksud pada ayat (1) diberikan kompensasi: a. Masa kerja 1 (satu) tahun sampai dengan 5 (lima) tahun diberikan sebesar RP.5.000.000 (lima juta rupiah). b. masa kerja lebih dari 5 (lima) tahun dihitung sebesar Rp.1.000.000 (satu juta rupiah) per tahun dan jumlah kompensasi secara komulatif paling tinggi sebesar Rp.20.000.000 (dua puluh juta rupiah). 
ketentuan diangkat menjadi PNS akan diberhentikan dari masa jabatannya apabila telah habis oleh bupati/walikota serta mendapatkan kompensasi yang dihitung dari masa kerjanya.

Kepastian hukum bagi Sekretaris Desa yang menjabat saat ini tentu sudah tidak termasuk lagi dan terikat pada ketentuan Pasal 202 Ayat 3 UU Pemda yang terdahulu tersebut, sebab UU tersebut telah dicabut dan diberlakukan UU Pemda yang baru. Tidak ada ruang dan kesempatan bagi Sekretaris Desa yang menjabat saat ini untuk dapat diangkat menjadi PNS karena dasar hukumnyapun sudah tidak berlaku lagi. Jabatan Sekretaris Desa dalam ketentuan yang baru UU Nomor 9 Tahun 2015 tentang Pemda maupun didalam ketentuan pada UU Desa tidak ada satu pasal/ayat/muatan dalam peraturan tersebut yang memerintahkan jabatan Sekretaris Desa diisi oleh PNS, dengan begitu jabatan Sekretaris Desa diisi oleh PNS dengan kata lain sudah terputus sejak diundangkannya UU 23 Tahun 2014 tentang Pemerintahan Daerah.

Selanjutnya timbul pertanyaan hukum lainnya, lantas bagaimana keberlakuan PP Nomor 45 Tahun 2007 tentang Persyaratan dan Tata Cara Pengangkatan Sekretaris Desa Menjadi Pegawai Negeri Sipil dan bagaimana keberlakuan Permendagri Nomor 21 Tahun 2008 tentang Perubahan Atas Peraturan Menteri Dalam Negeri
Nomor 50 Tahun 2007 tentang Ketentuan Pelaksanaan Peraturan Pemerintah Nomor 45 Tahun 2007 tentang Persyaratan dan Tata Cara Pengangkatan Sekretaris Desa Menjadi Pegawai Negeri Sipil dilihat dari sudut pandang ilmu perundang-undangan.

Terhadap pertanyaan hukum tersebut tentu harus dijawab dengan lugas dan mendasar, secara doktrin dalam Peraturan Perundang-undangan menyatakan bahwa Pertama, sebuah peraturan perundangundangan hanya bisa dicabut atau tidak berlaku lagi apabila telah dinyatakan secara tegas ketentuan tersebut mencabut ketentuan oleh produk hukum yang selevel (horizontal). Misalnya dalam hal ini ialah UU 32 Tahun 2004 telah dicabut dan dinyatakan tidak berlaku dengan diundangkannya UU 23 Tahun 2014 tentang Pemerintahan Daerah ${ }^{12}$. Kedua, Termasuk pula ketidak-berlakuan sebuah norma hukum secara hukum tidak berlaku apabila

\footnotetext{
${ }^{12}$ Lihat Konsiderat menimbang huruf d UU Nomor 23 Tahun 2014 tentang Pemerintahan Daerah. "bahwa Undang-Undang Nomor 32 Tahun 2004 tentang Pemerintahan Daerah tidak sesuai lagi dengan perkembangan keadaan, ketatanegaraan, dan tuntutan penyelenggaraan pemerintahan daerah sehingga perlu diganti" lihat juga ketentuan pasal 409 huruf b "Undang-Undang Nomor 32 Tahun 2004 tentang Pemerintahan Daerah (Lembaran Negara Republik Indonesia Tahun 2004 Nomor 125, Tambahan Lembaran Negara Republik Indonesia Nomor 4437) sebagaimana telah diubah beberapa kali terakhir dengan Undang-Undang Nomor 12 Tahun 2008 tentang Perubahan Kedua Atas Undang-Undang Nomor 32 Tahun 2004 tentang Pemerintahan Daerah (Lembaran Negara Republik Indonesia Tahun 2008 Nomor 59, Tambahan Lembaran Negara Republik Indonesia Nomor 4844); dicabut dan dinyatakan tidak berlaku”.
} 
dicabut oleh peraturan yang lebih tinggi. lalu yang terakhir ialah sifat dan karakter dari PP dan Permendagri tersebut termasuk dalam kategori delegated legislation.

Delegated legislation merupakan bentuk peraturan perundang-undangan yang bersifat delegasi dari peraturan yang lebih rendah untuk didelegasikan kepada pejabat/ organ/lembaga lain yang secara struktur berada di bawah pembuat peraturan asal untuk menindaklanjuti/ membuat bentuk aturan delegasi lanjutan guna melaksanakan isi/norma yang lebih tinggi tersebut. dalam hal ini delegated legislation ialah UU Pemda lama (Pasal 202) melahirkan delegated legislation bagi Pemerintah (Presiden) dengan dikeluarkannya PP Nomor 45 Tahun 2007 tentang Persyaratan dan Tata Cara Pengangkatan Sekretaris Desa Menjadi Pegawai Negeri Sipil dilihat dari sudut pandang ilmu perundang-undangan, termasuk pula melahirkan delegated legislation bagi lembaga kemendagri dengan mengeluarkan Permendagri Nomor 21 Tahun 2008 tentang Perubahan Atas Peraturan Menteri Dalam Negeri Nomor 50 Tahun 2007 tentang Ketentuan Pelaksanaan Peraturan Pemerintah Nomor 45 Tahun 2007 tentang Persyaratan dan Tata Cara Pengangkatan Sekretaris Desa Menjadi Pegawai Negeri Sipil.

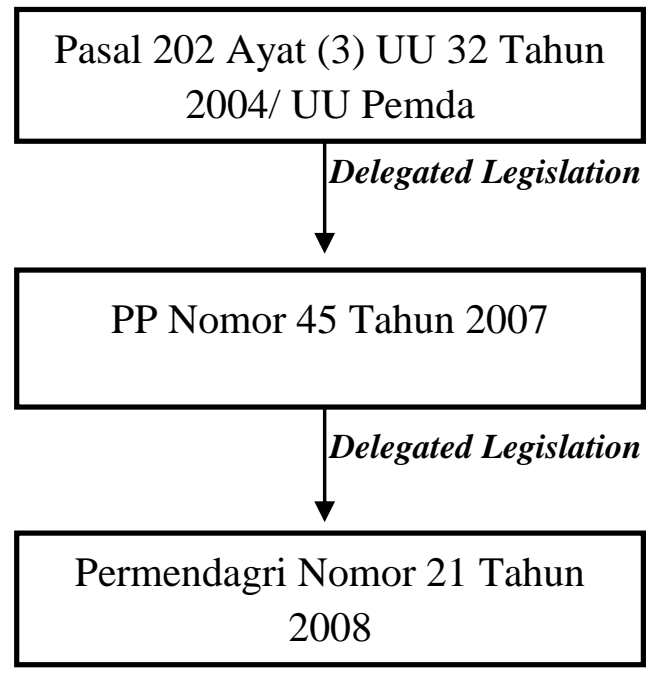

PP Nomor 45 Tahun 2007 dan Permendagri Nomor 21 Tahun 2018 merupakan delegated legislation dari UU Pemda terdahulu, khususnya pelaksanaan atas ketentuan Pasal 202 Ayat (3). PP Nomor 45 Tahun 2007 dan Permendagri Nomor 21 Tahun 2018 menjadi tidak berlaku secara otomatis tatkala cantolan pasal (termasuk UU Induknya) sudah dinyatakan dicabut dan tidak berlaku lagi. Jadi dari sudut pandang ilmu Perundang-undangan kedua peraturan perundang-undangan tersebut (demi hukum) secara otomatis tidak berlaku lagi meskipun secara nyata kedua peraturan tersebut tidak dicabut oleh pejabat/lembaga yang menerbitkannya, atau dengan kata lain tidak perlu tindakan pencabutan secara formil oleh Presiden atas keberlakuan PP Nomor 45 Tahun 2007 dan tidak diperlakukan pencabutan secara formil oleh Mendagri atas keberlakuan Permendagri Nomor 21 Tahun 2008.

Alasan yuridis lain yang dapat menunjudkan bahwa PP tersebut secara 
otomatis tidak berlaku lagi ialah dengan merujuk pada pengertian dari PP itu sendiri, Peraturan Pemerintah adalah Peraturan Perundang-undangan yang ditetapkan oleh Presiden untuk menjalankan UndangUndang sebagaimana mestinya. ${ }^{13}$ Atas dasar tersebut secara tegas pemaknaan yang dapat dipahami ialah lahirnya sebuah produk hukum berupa PP tersebut lahir karena untuk menjalankan perindah UU.

Merujuk pada PP 45 Tahun 2007 tersebut, maka secara tegas pula dinyatakan bahwa diterbitkannya PP tersebut karena terdapat alas dasar yang kuat yakni keberlakuan Pasal 202 pada UU Nomor 32 Tahun 2004/UU Pemda lama/terdahulu. ${ }^{14}$ Atas ketentuan dasar/cantolan hukum terbitnya PP tersebut maka apabila UU/termasuk pasal yang dirujuk telah dinyatakan dicabut dan tidak berlaku maka secara hukum (demi hukum) pula PP tersebut tidak berlaku.

\footnotetext{
${ }^{13}$ Lihat Pasal 1 Angka 5 Undang-Undang Republik Indonesia Nomor 15 Tahun 2019 tentang Perubahan Atas Undang-Undang Nomor 12 Tahun 2011 tentang Pembentukan Peraturan Perundangundangan.

${ }^{14}$ Lihat konsiderat menimbang a dan b PP 45 Tahun 2007 tentang Persyaratan dan Tata Cara Pengangkatan Sekretaris Desa Menjadi Pegawai Negeri Sipil. a. Bahwa sesuai dengan ketentuan Pasal 202 Undang-Undang Nomor 32 Tahun 2004 tentang Pemerintahan Daerah, Sekretaris Desa yang memenuhi persyaratan sesuai ketentuan peraturan perundang-undangan, akan diangkat secara bertahap menjadi Pegawai Negeri Sipil; b. bahwa berdasarkan pertimbangan sebagaimana dimaksud pada huruf a, perlu menetapkan Peraturan Pemerintah tentang Persyaratan dan Tata Cara Pengangkatan Sekretaris Desa menjadi Pegawai Negeri Sipil.
}

Peraturan Perundang-undangan memberikan kepastian hukum yang lebih nyata karna kaidah-kaidahnya mudah diidentifikasi dan mudah diketemukan kembali. ${ }^{15}$ Kepastian hukum pengangkatan Sekretaris Desa diisi oleh PNS (bagi yang menjabat saat ini) dengan diberlakukannya UU 23 Tahun 2014 (sebagaimana telah diubah dengan UU Nomor 9 Tahun 2015 tentang Perubahan Kedua UU Nomor 23 Tahun 2014 tentang Pemerintahan Daerah) terindikasi tertutup/ kepastian hukum bahwa jabatan Sekretaris Desa tidak diisi dari jabatan PNS.

Berdasarkan uraian dalam pembahasan tersebut diatas maka Sekretaris Desa yang menjabat saat ini sudah tidak memiliki peluang lagi untuk bisa diangkat menjadi PNS. Peluang tersebut sudah tertutup karena alas dasar hukum sebelumnya yakni ketentuan Pasal 202 ayat (3) pada UU 32 Tahun 2004 tentang Pemerintahan Daerah/UU Pemda lama/terdahulu sudah resmi dicabut dan tidak diberlakukan lagi, sebagai gantinya pemerintah telah mengeluarkan UU 23 Tahun 2014 tentang Pemerintahan daerah (terakhir diubah dengan UU Nomor 9 Tahun 2015 tentang Perubahan Kedua Atas Undang-Undang Nomor 23 Tahun 2014 tentang Pemerintahan Daerah.

\footnotetext{
${ }^{15}$ Bagir Manan, Dasar-Dasar Perundang-undangan di Indonesia, IND-HILL, Jakarta, 1992, hlm. 8
} 
Kedua, untuk membahas secara komprehensif atas rumusan masalah yang kedua ini yakni terkait bagaimana pengaturan kedepan terkait jabatan Sekretaris Desa, tentu tulisan/kajian ini mempunyai pandangan sendiri dan alasan-asalan ilmiah yang akan dikemukakan dan diulas dalam pembahasan kedua dalam penelitian ini yang akan dikaitkan dengan sebuah penyelenggaraan pemerintahan desa yang bersih dan baik/clean and good governance. Untuk memulai pembahasan tersebut maka akan di awali dari pengertian dari jabatan PNS itu sendiri.

PNS sendiri diatur dalam UndangUndang Republik Indonesia Nomor 5 Tahun 2014 tentang Aparatur Sipil Negara (selanjutnya akan ditulis UU 5 Tahun 2014/ UU ASN), dalam ketentuan tersebut pemerintah membangun apartur sipil negara yang memiliki integritas, profesionalitas, netral, dan bebas dari intervensi politik dan sebagainya. Berikut pengertian dari PNS itu sendiri.

Aparatur Sipil Negara yang selanjutnya disingkat ASN adalah profesi bagi pegawai negeri sipil dan pegawai pemerintah dengan perjanjian kerja yang bekerja pada instansi pemerintah.

Pegawai Aparatur Sipil Negara yang selanjutnya disebut Pegawai ASN adalah pegawai negeri sipil dan pegawai pemerintah dengan perjanjian kerja yang diangkat oleh pejabat pembina kepegawaian dan diserahi tugas dalam suatu jabatan pemerintahan atau diserahi tugas negara lainnya dan digaji berdasarkan peraturan perundangundangan.

Pegawai Negeri Sipil yang selanjutnya disingkat PNS adalah warga negara Indonesia yang memenuhi syarat tertentu, diangkat sebagai Pegawai ASN secara tetap oleh pejabat pembina kepegawaian untuk menduduki jabatan pemerintahan.

Pemerintah membagi ASN menjadi 2 (dua) yakni PNS dan Pegawai Pemerintah dengan Perjanjian Kerja, namun yang menjadi fokus bahasan disini ialah PNS. PNS dari pengertian tersebut memiliki tugas yang diberikan negara serta digaji oleh negara (tentu dengan APBN atau dengan APBD jika statusnya berada pada lingkungan pemerintahan daerah) guna menjalankan tugas pemerintahan.

Dalam menjalankan tugasnya tersebut PNS terikat pada fungsi, tugas dan peran yang menjadi pegangan bagi seorang PNS. ${ }^{16}$ Dengan begitu Sekretaris Desa yang

\footnotetext{
${ }^{16}$ Fungsi, tugas dan Peran PNS selaku ASN tersebut dapat dilihat pada ketentuan Pasal 10 dan Pasal 11 dan Pasal 12 Undang-Undang Republik Indonesia Nomor 5 Tahun 2014 tentang Apratur Sipil Negara. Pasal 10. "Pegawai ASN berfungsi sebagai: a. pelaksana kebijakan publik; b. pelayan publik; dan c. perekat dan pemersatu bangsa". Pasal 11 "Pegawai ASN bertugas: $a$. melaksanakan kebijakan publik yang dibuat oleh Pejabat Pembina Kepegawaian sesuai dengan ketentuan peraturan perundang-undangan; $b$. memberikan pelayanan publik yang profesional
} 
jabatannya diisi dari jabatan PNS juga termasuk menjunjung tinggi serta melaksanakan seluruh fungsi dan tugas Sekretaris Desa selaku PNS yang ditempatkan pada pemerintahan desa. Namun, seperti ulasan dalam pembahasan sebelumnya, saat ini jabatan Sekretaris Desa tersebut sudah tidak bisa lagi diisidari kalangan PNS karena regulasinya/pengaturannya sudah berubah.

Terhadap keadaan-keadaan yang saat ini tersebut, penelitian ini mendorong kepada pemerintah untuk melakukan perbaikan terhadap perubahan UU Desa. Struktur aparatur pemerintahan desa sendiri saat ini memang diatur seluruhnya pada UU Desa, namun pengadobsian jabatan Sekretaris Desa diisi oleh PNS tidak ada pada UU ini, oleh karena itu penelitian ini mendorong agar dapat kembalikannya aturan pengisian jabatan Sekretaris Desa diisi oleh PNS.

Terdapat nuasa yang sangat positif tatkala pengisian jabatan Sekretaris Desa diisi oleh PNS/kembalipada pengaturan terdahulu, beberapa alasan yuridis akan dipaparkan sebagai berikut:

Pertama, Sebagaimana telah dijelaskan di awal bahwa pemerintahan desa merupa-

dan berkualitas; dan c. mempererat persatuan dan kesatuan Negara Kesatuan Republik Indonesia". Pasal 12 "Pegawai ASN berperan sebagai perencana, pelaksana, dan pengawas penyelenggaraan tugas umum pemerintahan dan pembangunan nasional melalui pelaksanaan kebijakan dan pelayanan publik yang profesional, bebas dari intervensi politik, serta bersih dari praktik korupsi, kolusi, dan nepotisme". kan pemerintahan terbawah dalam sistem NKRI yang mana pemerintahan desa ini langsung berhubungan langsung dengan pelaksanaan pelayanan kepada masyarakat. Secara gambaran besar disini bahwa pemerintahan itu dapat di bagi menjadi 4 (empat) yakni Pemerintah Pusat, Pemerintah Provinsi, Pemerintah Kabupaten/ Walikota, dan Pemerintahan Desa. ${ }^{17}$

Pada tiap-tiap jenjang pemerintahan tersebut hampir didominasi jabatan dari pemerintahan tersebut diisi oleh ASN/PNS. Misalnya saja dalam Pemerintahan Pusat pada kementerian mulai dari Direktorat Jenderal pada masing-masing kementerian jabatannya diisi oleh kalangan PNS dari atas sampai bawah. Pemerintahan Provinsi selain kepada Daerah dan Wakil Kepala Daerahnya (Sekretaris Daerah Provinsi dan Satuan Organisasi Perangkat Daerahnya juga diisi oleh PNS). Pemerintah Kabupaten/Kota selain Bupati dan/Walikota

\footnotetext{
${ }^{17}$ Pemerintah Pusat (Presiden dan Wakil Presiden, Kementerian dan Lembaga Negara Struktural dan Non Struktural). Pemerintah Provinsi (Gubernur dan Wakil Gubernur dan Perangkat Daerah Provinsi). Pemerintah Kabupaten/Kota (Bupati dan Wakil Bupati, Walikota dan Wakil Walikota dan Perangkat Daerah Kabupaten/Kota). Dalam konteks ini tidak berarti menghilangkan eksistensi keberadan dari DPR RI, DPRD Provinsi, DPRD Kabupaten/Kota sebagai perangkat dan mitra dari tiap-tiap jenjang pemerintahan, (lembaga tersebut DPRD Provinsi/Kabupaten Kota dalam rezim UU pemerintahan Daerah merupakan unsur penyelenggara Pemerintahan Daerah) namun untuk memudahkan dalam penelitian ini lembaga tersebut tidak diikutsertakan karena penelitian ini fokus pada bidang eksekutif/bidang pemerintahan atau pemerintah daerah bukan pemerintahan daerah.
} 
(Sekretaris Daerah Kabupaten/Kota dan Satuan Oraganisasi Perangkat Daerahnya juga diisi oleh PNS).

Pemerintah Desa sendiri atau jenjang pemeirntahan keempat/terakhir ini tidak ada jabatan satupun yang dapat diisi oleh PNS apabila pengisian jabatan PNS itu sendiri tidak diisi oleh PNS. Tidak ada satupun jabatan ASN yang mewakili/ menduduki jabatan tertentu pada Pemerintahan Desa, padahal sudah ditegaskan pada pembahasan diawal jika pemerintahan desa ini sendiri merupakan bagian dari penyelenggaraan urusan pemerintahan yang langsung berhubungan dengan rakyat / masyarakat. Dengan alasan-alasan yuridis tersebut maka sebenarnya patut dipertimbangkan kembali memasukkan pengaturan terkait jabatan Sekretaris Desa diisi oleh PNS.

Kedua, jabatan-jabatan yang diisi dengan status PNS maka akan memberikan beban dan amanah yang berat bagi pemangkunya (orang yang memegang jabatan PNS tersebut). jabatan yang berstatus PNS secara otomatis akan meningkatkan kinerja dari seseorang yang menjabatnya tersebut, sebut saja yang termudah terkait jam kerja PNS yang tertib dan berkepastian, PNS juga terikat pada kode etik, dan yang terpenting apabila Sekretaris Desa diisi oleh PNS maka pemangku jabatan tersebut akan terikat pada fungsi, tugas dan peran yang sangat membantu/mendorong terciptanya pelayanan prima kepada masyarakat dan menciptakan clean and good governancel pemerintahan yang baik dan bersih.

Sekretaris Desa dalam perumpamaan merupakan otak/prosesor dalam management penyelenggaraan pemerintahan desa, sekretaris desa merupakan jabatan yang harus diisi oleh kalangan yang terdidik, proporsional, mampu melaksankan tugas secara efektif dan efisien, keterbukaan, memiliki kemampuan profesionalitas, dan dapat menjalankan pekerjaan secara transparan. Tuntutan-tuntutan tersebut akan lebih mudah dicapai dengan label jabatan PNS yang secara vertikal akan memdapatkan advokasi dari Komisi Aparatur Sipil Negara, dengan begitu pelayanan kepada masyarakat akan benar berjalan dengan baik.

Sekretaris Desa yang diisi oleh PNS akan mendapatkan Pendidikan dan Pelatihan (diklat), tentu diklat yang akan didapatkan oleh Sekretaris Desa yang diisi oleh PNS ini akan menambah wawasan dan pengalaman guna mendukung tugas dan kewajiban dari Sekretaris Desa. Diklat PNS sendiri memiliki tujuan sebagai berikut.: 1). Meningkatkan pengetahuan, keahlian, keterampilan, dan sikap perilaku untuk dapat melaksanakan tugas jabatan secara profesional dengan dilandasi ke-pribadian dan etika PNS sesuai dengan kebutuhan instansi. 2). Menciptakan aparatur yang mampu berperan sebagai pembaharuan dan perekat persatuan dan kesatuan bangsa 3). 
Memantapkan sikap dan semangat pengabdian yang berorientasi pada pelayanan, pengayoman dan pemberdayaan masyarakat. 4). Menciptakan kesamaan visi dan dinamika pola piker dalam melaksanakan tugas pemerintahan umum dan pengembangan demi terwujudnya kepemerintahan yang baik. ${ }^{18}$

Berdasarkan alasan-alasan dan argumentasi yang di bangun tersebut maka kedepan, pengaturan pengisian jabatan Sekretaris Desa diisi oleh PNS perlu diadakan kembali/Jabatan PNS diisi oleh PNS diatur dalam UU Desa. Terdapat 2 tindakan hukum pemerintah melalui bidang Peraturan Perundang-undangan untuk dilakukan perubahan atas UU Desa. Pertama adobsi Ketentuan Pasal 202 UU Pemda lama/terdahulu, kedua hapus aturan Pasal 48 dan Pasal 49 dalam UU Desa yang pada intinya Sekretaris Desa diangkat oleh Kepala Desa, penghapusan pasal tersebut sangat dibutuhkan dan relevan agar kedepan pengisian jabatan Sekretaris Desa diisi oleh PNS (yang memenuhi syarat untuk diangkat menjadi PNS).

Pasal 48 dan Pasal 49 UU sejak diundangkan dan diberlakukan dan mengikat pada penyelenggaraan urusan pemerintahan desa tentu memiliki dampak atas keberadaan beberapa jabatan Sekretaris Desa

18 Lihat Pasal 2 Huruf a, b, c, d Peraturan Pemerintah Republik Indonesia Nomor 101 Tahun 2000 tentang Pendidikan dan Pelatihan Jabatan Pegawai Negeri Sipil. yang telah disisi oleh PNS, Sekretaris Desa yang diisi oleh PNS pada akhirnya Pemerintah Daerah Kabupaten/Kota melakukan tindakan mutasi ke satuan/SKPD/ instansi lain atau tidak lagi menjabat sebagai Sekretaris Desa karena proses mutasi tersebut. ${ }^{19} \mathrm{Hal}$ ini disebabkan karena regulasi dalam UU desa mengamanatkan pengisian jabatan Sekretaris Desa dipilih oleh Kepala Desa Setempat

Pengisian jabatan Sekretaris Desa diisi oleh PNS ini tentu juga perlu kajian yang komprehensif terutama kajian terkait kekuatatan keuangan negara untuk menggajinya. Jika melihat hasil lansiran dari Badan Pusat Statistik, dalam wilayah NKRI sendiri setidak-tidaknya memiliki sekitar 9.020 Desa $^{20}$ (yang artinya akan ada calon Sekretaris Desa sebanyak 9.020 yang menjadi pertimbangan perhitungan jika memang status jabatannya tersebut diisi

${ }^{19}$ Dari berbagaimacam wilayah di indonesia, salah satu contoh ialah Pemerintah Kabupaten Cianjur Jawa Barat melakukan mutasi atas 182 Sekretaris Desa yang berstatus PNS dimutasi di Organisasi Perangkat Daerah atau Ke Kantor Kecamatan sesuai kebutuhan. Selengkapnya lihat http://m.mediaindonesia.com/nusantara/209698/rat usan-pns-penjabat-sekdes-dimutasi. Diakses pada 22 Januari 2021.

${ }^{20}$ Data tersebut merupakan data lansiran resmi yang dikeluarkan oleh Badan Pusat Statistik, bisa saja jumlah sekdes tidak sebanyak data tersebut diatas karena angka tersebut(9.020) merupakan gabungan antara desa dan kelurahan, sebagaimana telah diketahui bahwa khusus untuk wilayah kelurahan pengisian jabatan sekretaris lurah statusnya memnag sudah diisi oleh PNS. selengkapnya lihat http://www.bps.go.id/dynamictable/2015/09/18\%2 000:00:00/906/jumlah-desa-kelurahan-menurutprovinsi-dan-letak-geografis-2003---2018.html diakses pada 22 Januari 2021. 
oleh PNS, atau sebagai pertimbangan atas jabatan PNS yang telah diangkat PNS dan belum memasuki masa pensiun dapat ditarik kembali pada desa asal/desa pertema kali yangbersangkutan diangkat menjadi Sekretaris Desa dengan status PNS.

\section{KESIMPULAN}

Kepastian hukum pengisian Jabatan Sekretaris Desa yang isi oleh PNS bagi mereka yang menjabat sebagai Sekretaris Desa saat ini menurut ilmu hukum dan Peraturan Perundang-undangan sudah tertutup/tidak dimungkinkan lagi. Hal tersebut diakibatkan karena cantolan hukum (pasal 202 Ayat (3) UU Pemda lama/ terdahulu) telah dicabut dan diganti dengan UU Nomor 9 Tahun 2015 tentang Perubahan Kedua Atas Undang-Undang Nomor 23 Tahun 2014 tentang Pemerintahan Daerah. UU Pemda yang baru tersebut didalam keseluruhan isi materiilnya tidak ada satupun yang mengamanatkan agar sekretaris desa diangkat menjadi PNS. Termasuk pula dalam UU Desa ketentuan tersebut tidak ada, sehingga status Sekretaris Desa saat ini tetaplah Aparat/Perangkat Pemerintahan Desa bersama-sama dengan Kepala Desa yang pengisiannya jabatannya ditentukan oleh Kepala Desa.
Kedepan pengaturan hukum terkait pengisian jabatan Sekretaris Desa diisi oleh PNS perlu dipertimbangkan kembali/ kembai diisi oleh PNS mengingat Sekretaris Desa berada pada pemerintahan desa/pemerintahan yang langsung berhubungan kepada masyarakat untuk memberikan pelayanan. Disamping itu pengisian Jabatan PNS bagi Sekretaris Desa akan mendorong sebuah pelayanan yang prima, menciptakan pemerintahan yang bersih dan baik, serta secara filosofis dengan adanya ASN/PNS yang dijabat oleh Sekretaris Desa maka pemerintah hadir pada pemerintahan desa. 


\section{DAFTAR PUSTAKA}

\section{Buku-buku}

Bagir Manan, Dasar-Dasar Perundangundangan di Indonesia, IND-HILL, Jakarta, 1992.

Dadang Sufianto, Pengantar Ilmu Pemerintahan, Pustaka Setia, Bandung, 2015.

Taliziduhu Ndraha, Metodologi Ilmu Pemerintahan, Rineka Cipta, Jakarta, 1997.

\section{Jurnal-Jurnal}

Didik Chusnul Yakin dkk, Pengaruh Implementasi Kebijakan,

Karakteristik Individu, Karakteristik Organisasi Terhadap Motivasi Kerja dan Kinerja Sekretaris Desa di Kabupaten Mojokerto. Jurnal Adminsitrasi Publik, Juni 2013, Vol. 11, No.1.

Irwan Tahir, Sejarah Perkembangan Desa di Indonesia, Desa di Masa Lalu, Masa Kini dan bagaimana Masa Depannya, Jurnal MIPI, Edisi 38 Tahun 2013, Jakarta.

Sadu Wasistiono dan M. Irwan Tahir, Prospek Pengembangan Desa, Fokus Media, Bandung, 2007.

Sutrino Purwohadi Mulyono, Sinergitas Penyelenggaraan Pemerintahan Desa Pasca pemberlakuan UU No. 6 Tahun 2014 tentang Desa, Jurnal MMH, Jilid 43 No. 3 Juli 2014.

\section{Peraturan Perundang-undagan}

Undang Undang Dasar Negara Republik Indonesia Tahun 1945.

Undang-Undang Republik Indonesia Nomor 9 Tahun 2015 tentang Perubahan Kedua Atas UndangUndang Nomor 23 Tahun 2014 tentang Pemerintahan Daerah.

Undang-Undang Republik Indonesia Nomor 15 Tahun 2019 tentang Perubahan Atas Undang-Undang Nomor 12 Tahun 2011 tentang Pembentukan Peraturan Perundangundangan.

Undang-Undang Republik Indonesia Nomor 5 Tahun 2014 tentang Aparatur Sipil Negara

Undang-Undang Republik Indonesia Nomor 6 Tahun 2014 tentang Desa.

Peraturan Pemerintah (PP) 45 Tahun 2007 tentang Persyaratan dan Tata Cara Pengangakatan Sekretaris Desa Menjadi Pegawai Negeri Sipil dan (Permendagri) Nomor 50 Tahun 2007 tentang ketentuan Pelaksanaan Peraturan Pemerintah Nomor 45 Tahun 2007 tentang Persyaratan dan Tata Cara Pengangkatan Sekretaris Desa Menjadi Pegawai Negeri Sipi.

Peraturan Pemerintah (PP) Republik Indonesia Nomor 101 Tahun 2000 tentang Pendidikan dan Pelatihan Jabatan Pegawai Negeri Sipil

Peraturan Menteri Dalam Negeri (Permendagri) Nomor 21 Tahun 2008 tentang Perubahan Atas Peraturan Menteri Dalam Negeri Nomor 50 Tahun 2007 tentang Ketentuan Pelaksanaan Peraturan Pemerintah Nomor 45 Tahun 2007 tentang Persyaratan dan Tata Cara Pengangkatan Sekretaris Desa Menjadi Pegawai Negeri Sipil. 


\section{Website}

http://m.mediaindonesia.com/nusantara/209 698/ratusan-pns-penjabat-sekdesdimutasi. Diakses pada 22 Januari 2021

http://www.bps.go.id/dynamictable/2015/09 /18\%2000:00:00/906/jumlah-desakelurahan-menurut-provinsi-dan-letakgeografis-2003---2018.html diakses pada 22 Januari 2021

\section{BIODATA SINGKAT PENULIS}

Dr. Muhammad Hoiru Nail, S.H., M.H. adalah Dosen pada Fakultas Hukum Universitas Islam Jember. Memperoleh gelar Sarjana Hukum pada Fakultas Hukum Universitas Jember Tahun 2012 dan memperoleh gelar Magister Hukum (M.H.) dari Fakultas Hukum Universitas Jember Tahun 2015. Gelar Doktor diselesaikan pada fakultas yang sama pada tahun 2020 .

Suphia, S.H., M.Hum. adalah Dekan Fakultas Hukum Universitas Islam Jember. Memperoleh gelar Sarjana Hukum pada Fakultas Hukum Universitas Jember (UNEJ) dan memperoleh gelar Magister Humaniora (M.Hum.) dari Program Pasca Sarjana Universitas Merdeka (Unmer) Malang. 